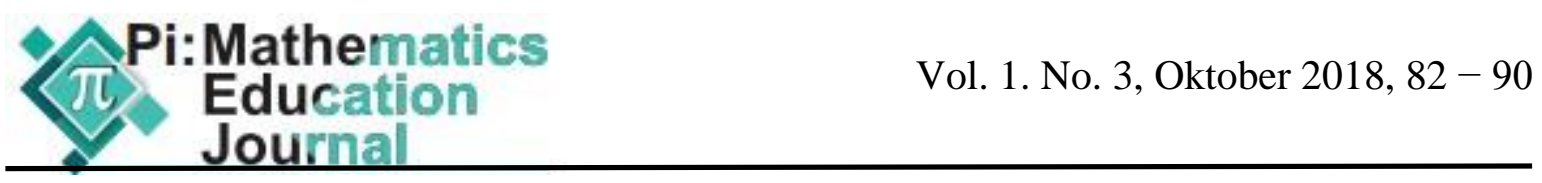

\title{
MENINGKATKAN KEMAMPUAN MATEMATIKA BERBASIS IT MAHASISWA TADRIS MATEMATIKA SEMESTER IV IAIN TULUNGAGUNG MELALUI SIKLUS SELF REGULATED LEARNING
}

\author{
Dewi Asmarani \\ Jurusan Tadris Matematika, Institut Agama Islam Negeri Tulungagung \\ Dewiasmarani.iain@gmail.com
}

\begin{abstract}
Abstrak: IAIN Tulungagung sebagai salah satu Perguruan Tinggi Negeri di Indonesia berkewajiban turut serta mewujudkan generasi muda yang cerdas, bermoral, berakhlak, kreatif, komunikatif, toleran dalam kehidupan dan tidak gagap teknologi. Semakin pesatnya kemajuanTeknologi dan Informasi (IT) sangat berpengaruh terhadap perubahan kurikulum di IAIN Tulungagung. Salah satu kurikulum yang telah berhasil diwujudkan adalah munculnya matakuliah Pembelajaran Matematika Berbasis IT. Untuk mencapai tujuan dari matakuliah tersebut diperlukan strategi khusus dalam mengajar. Banyak kendala yang harus dihadapi oleh dosen ketika mengajarkannya. Sebagai contoh kurangnya sikap kemandirian mahasiswa dalam belajar atau sering kita sebut dengan Self Regulated Learning (SRL). Rendahya SRL mahasiswa ini berdampak pada rendahnya keterampilan juga nilai akademik mahasiswa. Oleh karena itu tujuan dari penelitian ini adalah meningkatkan kemampuan Pembelajaran Matematika Berbasis IT mahasiswa melalui siklus SRL. Siklus tersebut terdiri dari beberapa fase. Adapun fase-fase yang dimaksud adalah fase perencanaan (forethought), fase menampilkan (performance), dan fase refleksi (reflection). Berdasarkan masalah di atas penelitian ini adalah penelitian kualitatif. Adapun subjek penelitiannya adalah mahasiswa Semester IV A Jurusan Tadris Matematika IAIN Tulungagung. Sedangkan instrumen yang digunakan untuk mengumpulkan data penelitian adalah lembar observasi, lembar tugas, dan lembar tes praktik. Dan hasil yang didapatkan sangat baik. Hal ini ditunjukkan dengan semakin meningkatnya kemampuan akademik dan terampilnya mahasiswa dalam mengoperasikan berbagai macam software baru seperti Maple, Autoplay, Geogebra, Lectora Inspire, dan SPSS.

Kata Kunci: Self Regulated Learning; Matematika; IT.
\end{abstract}

\section{Pendahuluan}

Semakin pesatnya kemajuan Teknologi dan Informasi (IT) sangat berpengaruh terhadap kemajuan pendidikan saat ini. Pengaruh yang ditimbulkan oleh kemajuan IT ini berdampak pada perubahan kurikulum di sekolah-sekolah termasuk di Perguruan Tinggi. Perubahan kurikulum yang dimaksud adalah munculnya matapelajaran atau mata kuliah yang bermuatan IT. Adapun salah tujuan dari perubahan ini adalah guna mewujudkan siswa yang terampil dalam bidang IT atau lebih dikenal siswa yang tidak gagap teknologi (gaptek). Hal ini sejalan dengan pendapat Mas'ud (2014) yang mengatakan bahwa perbaikan terhadap kurikulum dilakukan secara kontinyu dan berkesinambungan. Sehingga siswa menjadi lebih cerdas, bermoral, berakhlak, kreatif, komunikatif, dan toleran dalam kehidupan.

IAIN Tulungagung sebagai salah satu Perguruan Tinggi Negeri di Indonesia berkewajiban turut serta untuk mewujudkan cita-cita luhur tersebut. Mewujudkna mahasiswa yang cerdas dan tidak gaptek merupakan salah satu impian yang ingin dicapai. Dengan 36 jurusan yang sudah ada, IAIN berupaya memasukkan muatan IT disetiap kurikulumnya. Sebagai contoh salah satunya ada di Jurusan Matematika. Di 
jurusan ini terdapat satu matakuliah yang disebut matakuliah Pembelajaran Matematika Berbasis IT. Tujuan dari matakuliah ini adalah mahasiswa terampil dalam mengopersikan beberapa software matematika. Software yang dimaksud adalah Maple, Geogebra, Autoplay dan beberapa software yang lain.

Bukanlah hal mudah mengajarkan beberapa software yang dimaksud di atas kepada mahasiswa. Beberapa kendala sering dihadapi oleh dosen pengampu matakuliah Pembelajaran Matematika Berbasis IT tersebut. Kendala yang dihadapi diantaranya adalah mahasiswa terlihat pasif karena hanya menunggu intruksi dosen saja, waktu yang terbatas membuat mereka hanya mampu mempelajari satu software tidak lebih, dan motivasi mahasiswa dalam belajar terlihat hanya di awal perkuliahan saja.

Jika melihat kendala yang terjadi maka dosen perlu menganalisa hal-hal yang menjadi akar permasalahan munculnya kendala tersebut. Dari hasil diskusi dan wawancara dengan beberapa mahasiswa IAIN Tulungagung Jurusan Matematika pada hari selasa, 6 Februari 2018 tampaknya mahasiswa dituntut untuk lebih mandiri dalam belajar. Mandiri dalam belajar ini lebih sering kita sebut dengan Self Regulated Learning (SRL). Dengan SRL mahasiswa dituntut untuk lebih bertanggung jawab terhadap tugas dan kewajibannya.

Self Regulated Learning (SRL) adalah kemampuan individu yang aktif dan konstruktif dalam mengatur interaksi antara kognisi, motivasi, dan perilaku (Malmberg, dkk, 2014). Pengaturan kognisi mengharuskan siswa terlibat untuk mengadaptasi atau mengubah kognisinya melalui aktivitas pengulangan, elaborasi, dan organisasi. Pengaturan motivasi melibatkan aktivitas pengaturan semua pemikiran untuk fokus pada tujuan yang ingin dicapai, mengontrol strategi yang digunakan, adaptif dan mampu mempertahankan pendapatnya. Pengaturan perilaku melibatkan aktivitas pengaturan usaha, waktu, lingkungan, dan pencarian bantuan (Zimmerman, 2008).

Berdasarkan definisi SRL di atas maka dapat disimpulkan bahwa betapa pentingnya mengembangkan SRL mahasiswa dalam belajar. Dengan SRL ini diharapkan mahasiswa lebih mandiri, menyadari tanggungjawabnya, serta menyadari kemampuan dirinya meliputi segala kelebihan dan kekurangannya. Hal ini sejalan dengan pendapat Gandhi dan Varma (2007) yang menyatakan bahwa siswa yang memiliki SRL menyadari apa yang dilakukannya dalam belajar dengan memahami mengapa aktivitas itu dilakukan dan apa implikasinya.

Perlunya pengembangan SRL pada individu yang belajar matematika juga didukung oleh beberapa hasil studi temuan antara lain adalah: Individu yang memiliki SRL yang tinggi cenderung belajar lebih baik, mampu memantau, mengevaluasi, dan mengatur belajarnya secara efektif; menghemat waktu dalam menyelesaikan tugasnya; mengatur belajar dan waktu secara efisien, dan memperoleh skor yang tinggi dalam pengetahuan (Schunk \& Zimmerman, 2007; Zimmerman, 2008). Hasil penelitian Darr \& Fisher ( 2004) menunjukkan seorang pemecah masalah yang melaksanakan Self Regulated Learning berusaha untuk menganalisis, merencanakan, mengeksplorasi dan merefleksi untuk memahami situasi dari masalah yang dihadapi.

Untuk mengembangkan SRL mahasiswa dalam belajar, Zimmerman (2008) menawarkan siklus belajar yang terdiri dari beberapa fase. Fase tersebut dikenal dengan fase SRL. Adapun fasefase yang dimaksud adalah fase perencanaan (forethought), fase menampilkan (performance), dan fase refleksi (reflection). Dalam fase 
perencanaan, mahasiswa belajar untuk menentukan tujuan dan merencanakan strategi pemecahan masalah yang dihadapinya. Fase menampilkan, mahasiswa melaksanakan rencana yang telah disusun dan memantau efektivitas strategi tersebut. Sementara itu dalam fase refleksi, mahasiswa mengevaluasi efektifitas hasil belajarnya. Berikut adalah gambar ketiga fase tersebut yang lebih dikenal dengan Fase SRL.

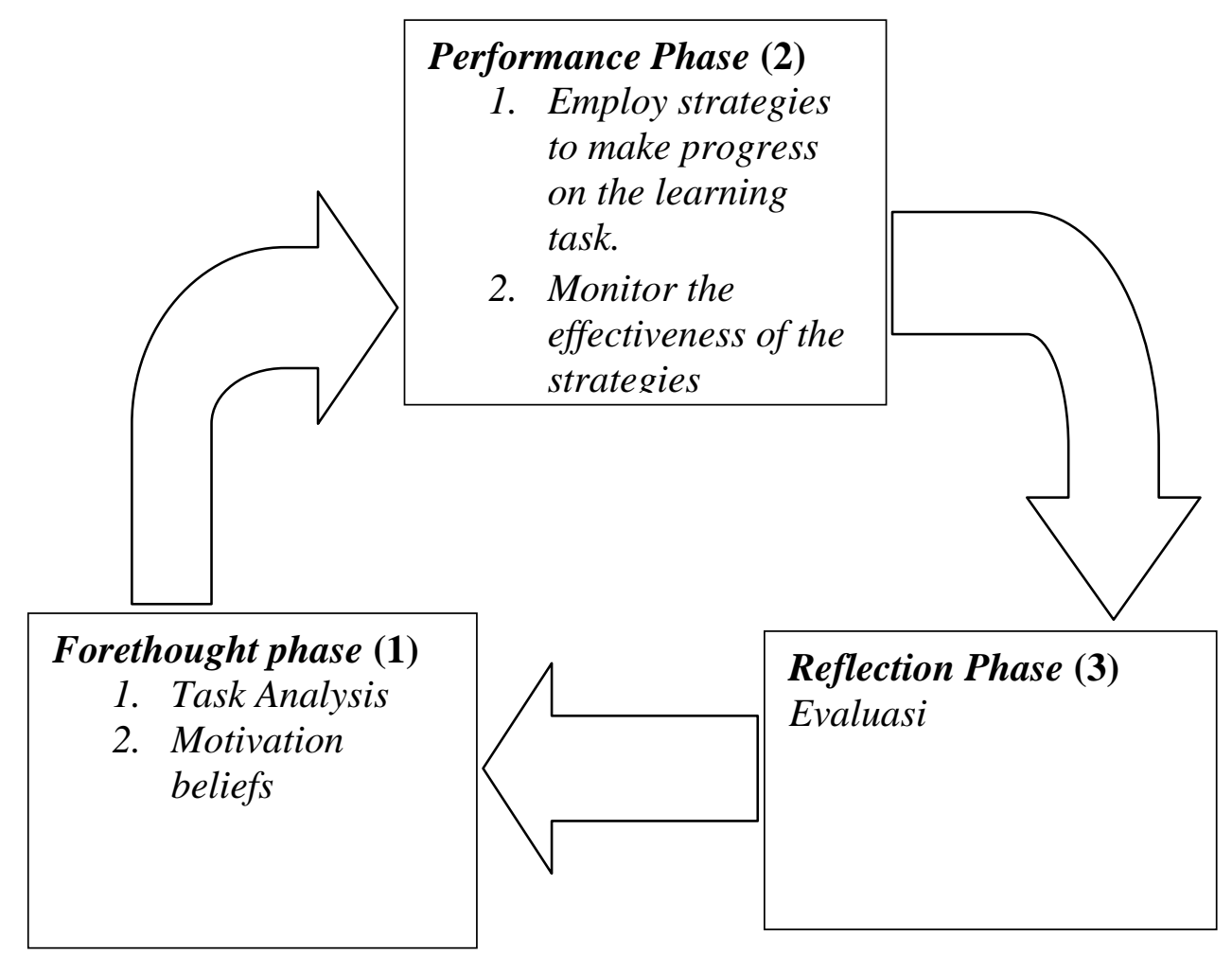

Gambar 1. Fase Self Regulated Learning Diadaptasi dari Zimmerman (2008).

Ketiga fase tersebut dikemas melalui tugas yang akan diberikan kepada mahasiswa. Tugas yang diberikan menuntut penyelesaian secara sistematis, memungkinkan mahasiswa dapat berpikir lebih sensitif terhadap feedback. Mahasiswa diharapkan dapat belajar dari kesalahannya dan tidak mengulangi kesalahan yang sama dimasa datang. Selain itu evaluasi kegiatan memudahkan mahasiswa dapat memetakan tingkat kesulitan tugas dan mempermudah mengenali bagian yang sulit dari tugas tersebut.

Dari uraian di atas, melalui tugas yang terencana diharapkan dapat mengembangkan SRL mahasiswa sehingga kendala-kendala yang muncul dalam proses pembelajaran Matematika Berbasis IT dapat teratasi dengan baik guna mewujudkan mahasiswa yang lebih cerdas, bermoral, berakhlak, kreatif, komunikatif, toleran, dan tidak gaptek dalam kehidupan.

\section{Metode Penelitian}

Jenis penelitian yang digunakan adalah penelitian kualitatif Deskriptif. Adapun subjek penelitiannya adalah mahasiswa Semester IV A Jurusan Tadris Matematika IAIN Tulungagung. Sedangkan instrumen yang digunakan untuk mengumpulkan data penelitian adalah lembar observasi, lembar tugas, dan lembar tes praktik. 
Sesuai dengan jenis penelitian yang digunakan, maka data yang terkumpul dalam penelitian ini dianalisis dengan menggunakan metode analisis data kualitatif. Adapun metode analisis data meliputi:

1. Mereduksi Data

Mereduksi data dilakukan dengan menyeleksi dan menyederhanakan data mentah yang diperoleh dari berbagai sumber yang ada di lapangan. Data yang dimaksud adalah hasil observasi, hasil tugas dan hasil tes praktik.

2. Penyajian Data

Penyajian data dilakukan untuk memaparkan secara naratif sekumpulan informasi yang telah diperoleh dari hasil reduksi sehingga memberikan kemungkinan penarikan kesimpulan. Informasi yang dimaksud adalah uraian kegiatan pembelajaran, hasil observasi, hasil tugas dan hasil tes praktik.

3. Penarikan Kesimpulan

Penarikan kesimpulan merupakan intisari dari analisis yang memberikan pernyataan tentang dampak dari Penelitian maupun efektifitas pembelajaran yang dilakukan.

\section{Hasil dan Pembahasan}

Hasil observasi dari penelitian ini menunjukkan bahwa dosen telah mampu mengawali pembelajaran dengan memberikan tugas yang terencana. Tugas yang diberikan adalah tugas kelompok berupa belajar software matematika secara otodidak. Tugas ini diberikan kepada masing-masing kelompok. Setiap kelompok mendapatkan tugas belajar software yang berbeda. Adapun software yang dipelajari adalah Maple, Autoplay, Geogebra, Lectora Inspire, dan SPSS.

Dalam rangka mengembangkan SRL Mahasiswa maka dosen berupaya melaksanakan dan mendukung mahasiswa merefleksi keterlibatannya dalam siklus 3 fase SRL. Misalnya, untuk mendukung mahasiswa dalam menyelesaikan tugasnya dosen mulai membantu mereka menganalisis tugas yang diberikan. Mahasiswa diminta untuk menjelaskan informasi yang didapat (misalnya informasi yang diberikan dalam tugas tersebut). Mereka diminta untuk mengidentifikasi dan menerapkan strategi untuk memenuhi persyaratan tugas (misalnya pengorganisasian yang diberikan informasi, menemukan hubungan antara informasi yang diberikan dan apa yang diminta dalam tugas). Selain itu mahasiswa diminta untuk mengevaluasi sendiri hasil yang sesuai dengan kriteria tugas (misalnya seberapa cepat mereka mampu menyelesaikan tugas? Apakah ada metode lain untuk menyelesaikan tugas yang sama?) dan untuk memperbaiki tugas mereka diberikan pilihan strategi khusus sehingga tugas terselesaikan (misalnya adalah metode yang mereka pilih salah satu harus bagus, untuk menilai strategi yang paling tepat untuk menyelesaikan tugas?).

Sebuah penekanan utama adalah selama pelaksanaan perkuliahan matematika berbasis IT ini mahasiswa menyelesaikan tugas-tugas akademis mereka untuk berpikir tentang apa yang akan dilakukan pada diri mereka sendiri ketika dosen tidak bersama mereka. Oleh sebab itu selama perkuliahan di kelas dosen perlu memandu mahasiswa dalam proses kognitif mereka sehingga mereka menjadi sukses. Dosen campur tangan hanya bila diperlukan saja tidak langsung menjelaskan konsep yang diberikan. Dari perspektif teoritis hal itu bisa dikatakan bahwa jika instruksi semata-mata berfokus pada penjelasan langsung dari strategi yang telah ditetapkan, mahasiswa dapat secara tidak sengaja dikeluarkan dari pusat pengaturan diri dalam proses penyelesaian tugas (Butler, 1993, 1995).

Jika seorang dosen menganalisis tugas, mengantisipasi masalah, dan 
menetapkan strategi yang berguna, maka mahasiswa akan memiliki sedikit kesempatan untuk menyelesaikan tugas sendiri dan belajar strategi baru. Untuk menghindari masalah ini, secara bersamasama dosen dan mahasiswa mengkonstruksi strategi berdasarkan analisis tugas. Dosen dan mahasiswa bekerja bersama-sama untuk menemukan "solusi "(yaitu, strategi) untuk tugas yang diberikan. Sebagai contoh, ketika menentukan strategi untuk menyelesaikan tugas, mahasiswa mempertimbangkan strategi alternatif dalam mencari jalan terang dari tuntutan tugas (misalnya, strategi apa yang akan mereka adopsi untuk menyelesaikan tugas, mereka menggunakan media, menggambar diagram atau melakukan tebakan, memeriksa, dll). Sementara bekerja melalui tugas kolaboratif, mahasiswa didukung untuk mencoba strategi alternatif (misalnya, menerapkan strategi penyelesaian tugas yang berbeda untuk menyelesaikan tugas), menilai efektivitas strategi (misalnya, apakah mereka menemukan ide penyelesaian tugas atau strategi penyelesaian yang paling tepat), dan memodifikasi strategi yang sesuai. Seiring waktu, melalui proses interaktif, para mahasiswa sebaiknya belajar bagaimana membangun strategi yang efektif untuk mengatasi berbagai masalah dalam menyelesaikan tugas.

Implikasinya secara umum adalah bahwa dosen harus:

1. Bekerja sama dengan mahasiswa untuk melengkapi kerja yang bermakna (untuk membangun konteks komunkasi).

2. Mendiagnosa kekuatan dan tantangan mahasiswa dengan mendengarkan secara hati-hati ungkapan mahasiswa saat mereka melakukan kerja yang bermakna.

3. Melibatkan mahasiswa dalam bekerja sama menyelesaikan tugas ketika bekerja berusaha mencapai tujuan tugas.

4. Memberikan dukungan kepada mahasiswa agar proses kognitif berjalan efektif.

5. Penggunaan bahasa yang mudah dipahami sangatlah penting dalam diskusi interaktif mahasiswa untuk memahami pengalaman.

6. Meminta mahasiswa untuk mengartikulasikan ide-ide (misalnya, tentang kriteria tugas, strategi yang produktif) dalam kata-kata sendiri untuk mempromosikan pengetahuan baru. Misalnya, dosen dan mahasiswa berkomunikasi mendiskusikan tentang berbagai hal terkait dengan penyelesaian tugas (berkolaborasi untuk menyelesaikan berarti kerja).

Dosen mulai dengan meminta mahasiswa untuk berpikir keras dan berdiskusi dengan rekan-rekan mereka saat mereka bekerja (Mendiagnosis kekuatan dan tantangan). Perhatian berfokus pada bagaimana mereka menafsirkan tugas mereka (masalah yang diberikan, memahami konsep-konsep masing-masing software, menggambarkan masalah, mengidentifikasi strategi solusi, menerapkan prosedur, dan memantau pekerjaan mereka bersama-sama. Kemudian, seperti dijelaskan sebelumnya, dosen membantu mahasiswa untuk bekerja secara rekursif melalui siklus analisis tugas, menggunakan strategi, dan memantau diri (berkolaboratif menyelesaikan tugas ketika ingin mencapai tujuan tugas). Ketika kelompok melakukan dengan baik, dosen akan mendukung keberhasilan mereka dan merefleksikan strategi yang mereka gunakan dalam bekerja.

$\begin{array}{cr}\text { Para mahasiswa } & \text { siswa } \\ \text { mendokumentasikan strategi } & \text { yang } \\ \text { diterapkan melalui catatan } & \text { pribadi yang }\end{array}$


dapat mereka review, tes, dan disempurnakan dari waktu ke waktu. Ketika mereka mengalami kesulitan. Dosen membantu mahasiswa untuk menyelesaikan tugasnya agar lebih efektif (dengan dukungan). Misalnya, kadangkadang kembali mencari arah perhatian dengan memberikan contoh masalah dan mendukung mereka untuk menginterpretasikan informasi tersebut. Para mahasiswa membuka wawaasan baru dan mencoba ide-ide baru. Dengan demikian secara bersama mahasiswa telah mampu membangun strategi personalisasi berdasarkan pada diskusi interaktif antara dosen-dosen dan teman sebaya.

Dari hasil tugas mahasiswa yang diberikan kepada lima kelompok yang berbeda menunjukkan hasil kerja yang sangan memuaskan sekali. Berikut adalah hasil kerja dari masing-masing kelompok.

1. Hasil Kerja Kelompok Satu

Hasil kerja yang ditunjukkan oleh kelompok satu menunjukkan bahwa secara garis besar mahasiswa telah mampu menceritakan Maple itu sendiri, cara pengaplikasiannya, dan manfaatnya seperti kutipan berikut. Maple adalah suatu program (software) untuk keperluan bidang matematika. Aplikasi Maple 17 sangat canggih dan sangat membantu sekali dalam menyelesaikan permasalahan matematika. Mulai dari membuat persamaan, grafik, mencari nilai suatu fungsi, mencari limit, mencari integral dan masih banyak lagi materi matematika. Maple mempunyai banyak versi dan latest versionnya (versi terbarunya) kini sudah menginjak versi 18.

Selain itu kelompok satu berhasil menganalisis kelebihan dan kekurang Maple itu sendiri seperti berikut.

Kelebihan Maple:

Mempermudah penyelesaian
komputasi matematika b. Membantu penggunaan untuk melakukan pengerjaan rutin berkaitan dengan bidang matematis

c. Menyelesaikan persoalan-persoalan matematika seperti aljabar, kalkulus, matematika diskrit, numerik dan masih banyak lagi yang lain dengan cepat dan efisien karena di dalamnya sudah terdapat fitur-fitur yang dapat mempermudah

cara menggunakannya.

d. Dapat membuat grafik baik dua dimensi maupun tiga dimensi serta fungsi parametrik.

e. Dapat melakukan operasi matematika secara numerik dan simbolis

f. Perhitungan matematika dapat dilakukan dengan langsung

g. Dapat melakukan perhitungan pecahan tanpa harus mengkonversikannya ke desimal telebih dahulu

h. Dalam peritungan matematis jumlah digit tidak memiliki batas

Kekurangan Maple:

Maple belum bisa melakukan perhitungan yang terus menerus seperti dalam mengerjakan metode biseksi, metode regula falsi dan lain-lain. Walaupun Maple tergolong software matematika yang gampang digunakan tetapi jika dalam menggunakan rumus dan simbol-simbol dalam menyelesaikan permasalahan salah, maka akan fatal akhibatnya.

2. Hasil kerja Kelompok Dua

Hasil kerja kelompok dua menunjukkan bahwa mahasiswa telah mampu menjelaskan dan mengaplikasikan tentang:

a. Aplikasi Geogebra

b. Fungsi menu Geogebra

c. Fungsi peralatan Geogebra fungsi linear

d. Fungsi kuadrat

e. Fungsi polinom

f. Fungsi trigonometri 
g. Fungsi eksponen

h. Fungsi logaritma

i. Menyelesaiakan persamaan

j. Menyelesaiakan sistem persamaan

k. Persamaan garis lurus

1. Persamaan parabola

m. Persamaan hiperbola

n. Lingkaran

o. Persamaan elips

p. Persamaan

q. Integral tak tentu

r. Integral tentu

s. Turunan

t. Turunan implisit

u. Membuat jajar genjang menjadi prisma

v. Membuat jaring-jaring

w. Jarak titik ke garis

x. Jarak titik ke bidang

y. Sudut antara dua garis

z. Sudut antara garis dan bidang

aa. Sudut antara dua bidang

bb. Operasi matriks

cc. Determinan matriks

dd. Invers matriks

ee. Mencari mean, median, modus

ff. Mencari quartil dan standar deviasi

gg. Menggambar histogram

hh. Cara cepat mencari mean, median, modus

Hasil kerja dari kelompok dua ini

dapat dikatakan sangat memuaskan, sebab terdapat banyak sekali materi matematika yang telah dikuasai mahasiswa dengan menggunakan Geogebra. Bahkan mereka mampu menyelesaikan masalah-masalah yang muncul ketika kelompok lain mengajukan beberapa soal yang sulit untuk diselesaikan. Dengan sigap kelompok dua menggunakan Geogebra telah berhasil menjawabnya.

3. Hasil kerja Kelompok Tiga

Hasil kerja kelompok tiga menunjukkan bahwa mahasiswa telah mampu menjelaskan tentang Lectora Inspire sebagai sebuah program komputer (software) yang berupa alat (tool) untuk pengembangan pembelajaran berbasis elektronik. Lectora Inspire sebagai Authoring Tool untuk pengembangan konten e-learning yang dikembangkan oleh Trivantis Corporation. Lectora Inspire juga sebagai salah satu program aplikasi yang dapat digunakan untuk membuat presentasi maupun media pembelajaran. Kelompok tiga juga telah berhasil menjelaskan keunggulan Lectora Inspire sebagai user friendly yang "mudah digunakan" dalam pembuatan media pembelajaran dan dapat membuat materi uji atau alat evalusi. Berikut materi yang berhasil dijelaskan:

a. Pengertian Lectora Inspire

b. Tampilan antar muka Lectora Inspire

c. Kegunaan Lectora Inspire

d. Kelebihan dan kelemahan Lectora Inspire

e. Fungsi toolbar

f. Aplikasi toolbar add object

g. Menambahkan teks

h. Menambahkan animasi

i. Menambahkan gambar

j. Menambahkan video

k. Menambahkan audio

1. Menambahkan character

m. Menambahkan flash

n. Menambahkan youtube video

o. Menambahkan equation

p. Menambahkan shape atau lines

q. Menambahkan date and time

r. Menambahkan page number

s. Menambahkan timer

t. Menyelipkan hyperlink

u. Membuat materi uji / soal

v. Penskoran

w. Aplikasi toolbar go to

x. Mencari skor akhir

4. Hasil kerja Kelompok Empat

Hasil kerja kelompok empat menunjukkan bahwa mahasiswa telah mampu menjelaskan secara rinci tentang Autoplay Media Studio sebagai software yang digunakan untuk membuat perangkat lunak multimedia dengan mengintegrasikan berbagai tipe media 
misalnya gambar, suara, video, teks dan flash ke dalam presentasi yang dibuat.

Selain itu perangkat lunak Autoplay Media Studio juga dapat digunakan untuk beberapa hal, antara lain sebagai berikut:

a. Pengembangan aplikasi multimedia

b. Aplikasi Computer Based Training (CBT)

c. Sistem Autoplay/AutoRun Menu CD-ROM

d. Presentasi Marketing interaktif

e. CD Business Cards

f. Dan lain-lain

5. Hasil kerja Kelompok Lima

Pengolahan dan Analisa Data merupakan dua proses yang sangat menetukan dalam pengolahan data menjadi suatu informasi. Kecepatan dalam pengolahan data ketepatan dalam analisa akan sangat menetukan kualitas informasi dan penulisan laporan dalam suatu kegiatan monitoring dan evaluasi, baik menggunakan data rutin maupun menggunakan data survei. Melalui SPSS kelompok lima telah berhasil mengolah dan menganalisa data melalui contohcontoh secara nyata yang mudah dipahami oleh peserta pemula. Adapun materi yang berhasil ditampilkan oleh kelompok lima adalah sebagai berikut:

a. Entri data SPSS

b. Analisis deskriptif

c. Analisis korelasi

d. Analisis komperasi

Tes praktik diberikan diakhir perkuliahan. Tes praktik ini diberikan dengan tujuan untuk mengetahui perkembangan kemampuan mahasiswa dalam mengoperasikan kelima software yang telah dipelajari. Dengan ketentuan, jika mahasiswa telah berhasil lolos menyelesaikan tes praktik yang diberikan dengan nilai minimal $\mathrm{B}$, maka mereka dianggap kemampuan mereka telah meningkat. Dari 42 mahasiswa yang ada di kelas TMT 4A hanya satu orang saja yang mendapatkan nilai $\mathrm{B}$ dan $\mathrm{B}+$. Sedangkan mahasiswa yang lain mayoritas mendapat nilai A dan A+. ini adalah prestasi yang luar biasa. Tampaknya perkuliahan yang dilakukan melalui tugas dan diselesaikan dengan siklus SRL memberikan dampak positif bagi dosen juga mahasiswa. Rata-rata mahasiswa telah mampu menguasai lima software yang berbeda. Hal ini sejalan dengan pendapat Schunk \& Zimmerman (2007) yang menyatakan bahwa individu yang memiliki SRL yang tinggi cenderung belajar lebih baik, dan memperoleh skor yang tinggi dalam pengetahuan.

\section{Kesimpulan}

Siklus SRL adalah proses yang membantu mahasiswa dalam mengelola pikiran, perilaku, dan emosinya agar berhasil mengarahkan pengalaman belajar mereka. Proses ini terjadi ketika belajar diarahkan pada tindakan pencapaian tujuan dan perolehan informasi atau keterampilan oleh mahasiswa. Umumnya, model SRL dipisahkan ke dalam fase-fase. Salah satu model siklus terpopuler dari SRL membahas tiga fase yang berbeda yaitu: fasepemikiran dan perencanaan, fase pemantauan kinerja, dan fase refleksi tentang kinerja. Selama fasepemikiran dan tahap perencanaan, mahasiswa menganalisa tugas belajar dan menetapkan tujuan yang spesifik dari tugas itu. Ketika mahasiswa belajar topik asing, namun, mereka tidak tahu cara terbaik untuk menyelesaikan tugas, dosen dan atau rekan-rekan yang lebih berpengalaman dapat menginstruksikan pendekatan yang efektif dalam menyelesaikan kasus-kasus seperti ini.

Selanjutnya, pada tahap pemantauan kinerja, mahasiswa menerapkan strategi untuk membuat kemajuan tugas belajar dan memantau efektivitas strategi tersebut, juga sebagai motivasi mereka untuk melanjutkan kemajuan menuju tujuan tugas. 
Sayangnya, ketika strategi baru muncul, mahasiswa kadang-kadang kembali menggunakan strategi lama yang mungkin tidak efektif lagi. Padahal dengan meluangkan waktu untuk berlatih dan belajar strategi baru dapat mengakibatkan pembelajaran lebih bermakna. Kemudian pemantauan dan umpan balik dosen yang spesifik dapat membantu mahasiswa belajar menggunakan strategi baru dengan kefasihan, terutama jika mahasiswa menghadapi kegagalan.

Terakhir, dalam fase refleksi mahasiswa mengevaluasi kinerja mereka. mahasiswa mengevaluasi efektivitas strategi yang mereka pilih. Selama tahap ini, mahasiswa juga harus mengelola emosi tentang hasil dari pengalaman belajar mereka. Hasil releksi diri ini kemudian mempengaruhi mahasiswa dalam perencanaan dan tujuan berikutnya, kemudian siklus dimulai kembali.

\section{Daftar Rujukan}

Gandhi, H., \& Varma, M. 2007. Promoting self-regulated learning in mathematics through some pedagogic strategies. Journal Indian Educational Review, 43(1).

Malmberg, J., Järvelä, S. \& Kirschner, P. A.2014. Elementary school students' strategic learning: Does task-type matter? Metacognition and Learning, November, 1-24.

Mas'ud, Muhammad. 2014. Membuat Mulimedia Pembelajaran dengan Lectora. Yogyakarta: Pustaka Shonif.

Pintrich, P.R. 2000. Self-regulation: Directions and challenges for future research. In M. Boekaerts \& P.R. Pintrich (Eds.), Handbook of selfregulation (hlm.749-768). San Diego, CA: Academic Press.

Schunk, D. \& Zimmerman, B. 2007. Influencing children's self-efficacy and self- regulation of reading and writing through modeling. Reading \& Writing Quarterly, 23(1): 7-25.

Zimmerman, B. 2008. Investigating selfregulation and motivation: Historical background, methodological developments, and future prospects. American Educational Research Journal, 45(1): 166-183. 